\title{
Wayang Orang Sriwedari Performance to Support Surakarta Tourism
}

\author{
Yuli Sectio Rini1 ${ }^{1, *}$ Herlinah $^{1}$ Supriyadi Hasto Nugroho ${ }^{1}$ Sutiyono $^{1}$ \\ ${ }^{1}$ Faculty of Language and Arts, Yogyakarta State University, Yogyakarta Indonesia \\ *Corresponding Author.Email:y_sectio@uny.ac.id
}

\begin{abstract}
Wayang Orang Sriwedari (Javanese operatic dance theatre) is a traditional art performance that is performed every night in the Sriwedari building in Surakarta. It is one of the performances that can be enjoyed by tourists at night when visiting the city. This study aims to investigate kinds of ways to perform Wayang Orang that will attract tourists thus improving the tourism sector. In this qualitative study, the data were collected through observation, interview, and literature study. The data were analyzed through data reduction, data presentation, conclusion drawing before they went through data triangulation to check the validity. The results of this study are related to the ways Wayang Orang Sriwedari is performed as a tourist attraction in Surakarta.
\end{abstract}

Keywords: Wayang Orang Sriwedari, Tourism, Performance

\section{INTRODUCTION}

The tourism sector that relies on the arts has not been fully exploited as a business. Even the potentials of art in Indonesia have not been used as an economic asset, both for locals and [3]. Even though traditional arts are very diverse and have the potential to be developed as a cultural tourism asset, especially in Central Java, there are only a few investors interested in turning the traditional arts into tourism commodities. Wayang Orang Sriwedari is a human puppet show that has been performed since PB X (Pakubowono XSurakarta Sultan) era between 1989 and 1939.

As the number of audiences in each show fluctuates, many printed and electronic media believe that this art performance is in a "coma". Thus, using all their efforts, people try to revive Wayang Orang, including changing the perspectives of the audience, cultural observers, and society. This means turning Wayang Orang Sriwedari into a positive view and making it an icon of the city of Surakarta which has evolved through times. This is done by making a similar perception that Wayang Orang involves various characters. Then, Wayang Orang performers are classified according to the characters that they play more specifically and change techniques and stage tricks during regular shows.

Due to this policy, Wayang Orang Sriwedari show has improved although it is not optimum. The number of audiences is increasing from time to time. However, the efforts to revive the show keep on going, people try to make innovations for deleting the belief that Wayang Orang is performed only for fun or that Wayang Orang will eventually disappear.

Whatever the situation is now, the number of audiences is still far from the expectation. In addition, the stage actors do not seem to show enthusiasm for playing on the shows because some of them are civil servants. Thus, they have days off on Sundays and holidays, and there are no shows on those days. Based on the collected data, most Wayang Orang dancers/stage actors are now civil servants. There are only a few young dancers who are not appointed by the Ministry of Tourism as civil servants. Therefore, the characters and story depend on the people available on the day they have performances. This more or less affects the stories and characters performed in the evenings.

Wayang Orang Sriwedari is one of the traditional art performances preserved by the city government. As a responsibility, the government needs to preserve the tradition as it has experienced ups and downs. In fact, it was almost forgotten by the community. Nowadays, Wayang Orang Sriwedari has survived [2]. However, the quality of the shows should be improving especially now that Sriwedari is facing challenges in the tourism 
industry. In this study, how Wayang Orang Sriwedari is performed as a tourist attraction is examined.

\section{LITERATURE REVIEW}

The tourism sector which relies on culture has not been fully exploited as a business. In fact, cultural potential Indonesia, in general, has not been considered as an economic asset, both for locals and investors [3]. In fact, traditional arts are very diverse and even have the potential to be developed as an asset for cultural tourism, especially in Central Java. Not many investors are interested in investing in traditional art as a tourism commodity [3].

Surakarta, the third largest tourist destination in Indonesia, has not relied on its cultural potential, especially for traditional arts for developing cultural tourism. It is clear that various traditional arts are not explored to attract tourists [3]. The cultural potential such as traditional arts is the biggest attraction for tourists, especially foreign tourists [3]. However, the city does not yet develop the asset into planned integrated tourism. Tourism activities are still running as they are due to limited human resources who are able to plan a cultural tourism package in order to attract both domestic and foreign tourists [3].

The impact of this unexplored cultural potential is that the level of tourist visits is very low. Thus, the opportunity to increase local community income and local government revenue are also low thus affecting job and business opportunities. On the one hand, art performance in general is now in a critical situation as it no longer has the economic and cultural aspects. One of the examples is Wayang Orang as traditional art performance in Surakarta. The place and schedule for Wayang Orang performances are now limited except for Wayang Orang Sriwedari that performs almost every day. The daily income for the show is around $\mathrm{Rp}$. $76,077.00$. This is very low as there are at least 70 people involved in the shows, such as Wayang stage actors, puppeteers, pengrawit (Javanese musical instrument stage actors), lighting technicians, stage, cleaning service, security, parking, etc [3].

Promotions are the element in an organization's marketing mix that serves to inform, persuade, and remind the market of the organization and or its product [5]. In other words, promotion is an element in the company's marketing used to persuade, inform, and attract people about the company's products (Saladin, 2006: 171) [5]. According to research, Surakarta Culture Office conducts organizational communication to carry out promotional activities for Wayang Orang as tourism potential. The activities carried out are to promote the art service to the public. The target is tourists who have an interest in the local culture, as well as fans of Wayang Orang from various communities and individuals.

Free shows are conducted to promote Wayang Orang. Besides, Surakartan government promotes Wayang Orang events on their website and at annual events. It is expected that Wayang Orang will gather as many enthusiasts as possible with the aim of measuring the success rate of the Cultural Service in promoting. Basically, traditional performing arts products can be "sold", both to enthusiasts consisting of our own communities and to foreigners as tourists [4]. Therefore, according to the Indonesian Ministry of Trade, performing arts are creative activities related to content development, performance production, ballet performances, traditional dances, contemporary dances, drama, traditional music, theater music, opera, including ethnic music tours, design, and manufacture of performance clothing, stage layouts, and lighting design.

In its development, Wayang Orang Sriwedari continues to gain a place in the hearts of the community who long for entertainment. Thus, the shows keep on develop rapidly. Some of the permanent stage actors who used to be buskers are appointed as servants in the palace as Punakawan Langentaya at the Hamongraras office of the Surakarta Palace. The prominent Wayang Orang Sriwedari stage actors in the era of the 20s to 40s are Wugu Hardjawibaksa who played Gatotkaca character and Sastradirun as Petruk [1].

\section{RESEARCH METHOD}

This research employed the qualitative research method. Using this method, researchers hoped that the various aspects being analyzed produced valid, reliable, and relevant data. Besides, as the objects were comprehensively analyzed, the data produced tended to be more accurate. The research was conducted at Sriwedari Performing Art Building, Surakarta, Central Java, Indonesia.

The data were collected through observation, interviews, and documentation. Observation was a method used by the researchers to see how Wayang Orang Sriwedari stage was prepared. Interview was done to investigate how stage actors and management staff prepare the show. Then, documentation was done to formulate and put terminology and theoretical sources in this study. Qualitative data were collected in this study. The technique used to analyze the data was the interpretive descriptive analysis technique. 


\section{RESULT AND DISCUSSION}

Building and stage are vital aspects of commercial performing art. The comfortable seats, good sound system, lighting, performance techniques, and environment are the physical elements that support the success of an art performance. The construction of Wayang Orang Sriwedari building started in 1942, and it was firstly used in 1951. It was only in 1977 that it was restored and improved with the help of the President of Republic of Indonesia. Some parts of the building were changed and replaced with new construction.

Since 1980, Wayang Orang Sriwedari has been under the management of Surakarta Tourism Office. Before that very year, the building and show were under Regional Revenue Service Office. In the organizational structure of the Surakarta City Tourism Office, Wayang Orang Sriwedari is managed by a special tourist attraction and guide division. The change in the employment status of Wayang Orang Sriwedari stage actors into civil servants is stipulated in a Surakarta City government decree. However, since 2001 the Wayang Orang Sriwedari has been under the Surakarta City Culture and Tourism Office in which the focus is on tourism.

The tourism sector which relies on culture has not been fully exploited as a business. In fact, cultural potential Indonesia in general has not been considered as an economic asset, both for locals and investors [3]. In fact, traditional arts are very diverse and even have the potential to be developed as an asset for cultural tourism, especially in Central Java. Not many investors are interested in investing in traditional art as a tourism commodity [3].

In this day and age, countless traditional arts in Indonesia from Sabang to Merauke can serve as material for tourist attractions in Indonesia. Culture such as traditional art is the biggest attraction for tourists [3]. Therefore, turning traditional arts into tourist attractions is the local government responsibility.

Surakarta, the third largest tourist destination in Indonesia, has not relied on its cultural potential, especially for traditional arts for developing cultural tourism. It is clear that various traditional arts are not explored to attract tourists [3]. Therefore, the Surakarta Tourism Office tries to develop traditional art into a tourist attraction.

From the large number of traditional arts that it possesses, Surakarta is considered ready to turn traditional art into a tourist attraction. Classical art in the Kasunanan and Mangkunegaran palaces and folk art are potential materials for tourism. However, the city does not yet develop the asset into planned integrated tourism. Tourism activities are still running as they are due to limited human resources who are able to plan a cultural tourism package in order to attract both domestic and foreign tourists [3].

Surakarta relies on Wayang Orang Sriwedari as a tourist attraction, so the government does coordination with management staff and Wayang Orang stage actors. The coordination needs to be maintained because it is a good start to achieve the goals. Surakarta Culture office is responsible for preserving the traditional art by providing facilities and infrastructure. In addition, the government should function as a formal policymaker whose job making coordination with the related community. This makes Wayang Orang promotion go well and have positive impacts on traditional art shows and the tourism sector. One of the efforts done is using information technology to publish information to people around the world.

Wayang Orang management staff now work under Surakarta City Government's Arts and Culture Tourism Office (Disparsenibud) in the Control and Preservation of Art and Cultural Assets division. This office is responsible for financially supporting production, providing salaries for all stage actors and staff, and providing maintenance costs for the building and all its facilities. The show production goes through two stages, namely planning and implementation done by production staff i.e. coordinator, director and assistant director, ticketing staff, Javanese musical instrument players, puppetry (wayang stage actor), costumes, and decoration.

Obeying the health regulation of COVID-19, the researchers conducted observation on June 26, 2020. It was found that the health regulation implemented includes the following aspects.

a. Limiting the number of audiences in the building.

b. Setting a seat distance of approximately 1 meter from seat to seat.

c. Requiring audiences to wear masks.

d. Requiring audiences to wash their hands before entering the performance hall.

e. Checking the audience's body temperature before entering the performance hall.

The atmosphere that night was much more tranquil than usual. The dialogues of the stage actors sounded clearer, the storyline seemed easier to understand, even for the lay audience of this show. Usually, the show started at 20.30 and ended at 23.00 with a duration of approximately 2 hours. At that time, it had to start earlier at 20.00 and end at 21.30, the duration was 1.5 
hours. Holding a Wayang Orang show during the Covid-19 pandemic, the management implemented health regulation. One of them is reducing the number of stage actors behind or on the stage so that they worked in shifts on Tuesday or Thursday.

Social distancing was done by dividing all Wayang Orang Sriwedari stage actors into two groups, from 77 people to 35 people per group. Thus, that there would not be a lot of stage actors on the stage in order to maintain the distance. The management had been given permission from the Mayor of Solo to hold a live performance, but the seating capacity was limited. Originally there would be 400-500 audiences, but they had only 100 seats or only 20 seats available during the pandemic. The tickets were sold online to reduce contact with visitors. Anyone interested in watching the Wayang Orang Sriwedari show should do a reservation and then transfer the money.

Each audience was assigned a seat number. The number was simply shown before entering the building. The ticket price did not increase. Before the COVID-19 pandemic, the VIP ticket was IDR 10,000, class 1 was IDR 7,500 and class 2 was IDR 5,000. Then, during the pandemic, all the seats were set as VIP tickets which cost IDR 10,000. For those who did not have time or could not buy tickets online, people could buy at the counter. However, the tickets might not be available because it provided only the remaining tickets sold in online sales. Besides, Wayang Orang Sriwedari also limited the age of the audience. Children under 12 years old and elderly over 55 years old were not allowed to watch the show inside the building. All visitors were also required to wear a mask, wash their hands and have their temperature checked. If their body temperatures were above 37.5 degrees Celsius, they were not allowed to enter the building.

The following are the results of observation on Wayang Orang Sriwedari performance on Friday, June 26, 2020. The show at that time was entitled "Sara Talpa". It was a story about Srikandi who exercised in front of Rishis Bharatayuda. She was sitting miserably on the mattress of Sara Talpa, lamenting the situation around her because she lost the Bharatayuda war. The war between the Kauravas and the Pandavas was then followed by karmic challenges. In his misery, Resi Bisma witnessed the figures of both the Kauravas and the Pandavas who were still alive continuing the war between Karna and Arjuna, which ended with Karna's death. Dewi Kunti, the mother of the two knights, blamed Resi Bisma for letting two of them fight until one died in the Bharatayuda war. Likewise, there was a battle between Duryudana and Bima which ended in Bima's victory. At that time, Resi Bisma was picked up by the wife of Dewi Amba to her meeting in death.
"Sara Talpa" was composed by involving gamelan tunes slendro and pelog, Javanese songs, and accompanied by songs with diatonic notes. The scenes were not presented in order but were highlighted based on needs, including the presence of entertaining clowns. Sara Talpa was performed like a dance drama.

\section{CONCLUSION}

Wayang Orang Sriwedari is a traditional art performed at Sriwedari building in Surakarta. It is one of the shows that can be enjoyed by tourists. Wayang Orang Sriwedari becomes a form of promotion of performing art. The government is responsible for preserving the art and tourism sector by making use of information technology and the internet, for example, Facebook, Instagram, and Twitter to promote the show. During this pandemic situation, the management of the shows strictly implements the health regulation of COVID-19 to reduce the spread and decrease the cases.

\section{REFERENCES}

[1] Atmanto, B.D. Komersialisasi Wayang Wong Tandai Lahirnya Wayang Orang Sriwedari [Wayang Wong: Marks the Beginning of Wayang Orang Sriwedari]. 2010.

http://www.timlo.net/baca/2927/komersialisasiwayang-orang-tandai-lahirnya-wayang-orangsiwedari/

[2] Kusharyani, Maharsidewi, Budi Santoso, and Fifiana Wisnaeni. Eksistensi Dan Perlindungan Wayang Orang Sriwedari Surakarta Ditinjau Dari Aspek Hukum Hak Cipta [The existence and protection of Wayang Wong Sri Wedari Surakarta in terms of legal and copyright aspects] Law Reform 12.1 (2016): 60-72. DOI: https://doi.org/10.14710/lr.v12i1.15841

[3] Markamah, dkk. Sejarah dan Kondisi Wayang Orang Sri Wedari [History and Condition Wayang Sri Wedari. Jurnal Penelitian Humaniora. Yogyakarta: Universitas Gadjah Mada. 2006.

[4] Munawaroh, Siti. Gandrung Seni Pertunjukan di Banyuwangi [Gandrung Performing Arts in Banyuwangi. Pengantar Redaksi (2007): 253.

[5] Saladin, Djaslim. Manajemen pemasaran [Marketing Management]. Edisi Keempat, Bandung: Linda Karya (2006). 